\title{
Customer Preferences of Housing Finance in Chennai with Special Reference to Sub Urban of Tambaram
}

\author{
Dr. A. Mahendra Kumar ${ }^{1}$, Dr K. Padmini², Dr. G. Manimannan ${ }^{3 *}$ \\ ${ }^{1}$ Assistant Professor of Commerce, TMG College of Arts and Science, Chennai. \\ ${ }^{2}$ Head of the Department, Department of Management Studies, TMG College of Arts and Science, Chennai. \\ ${ }^{3}$ Assistant Professor of Statistics, TMG College of Arts and Science, Chennai.
}

*Corresponding Author: Dr. G. Manimannan, Assistant Professor of Statistics, TMG College of Arts and Science, Chennai.

\begin{abstract}
In this paper an attempt is made to identify that there are key difference in the actual purchase of the consumers of housing loans of public sector banks, private sector banks and new generation public sector banks. As regard with the important product traits are concerned, litheness, processing fees, processing period and interest rates plays a vital role in all the three types of banks. Majority of the Customers prefer and avail their housing loan from Public and Private Sector bank. The customers visit and avail the housing loan in meager amount from new generation public sectors bank. The main objective of this study is to find the customer preference for housing loan from three categories of banks using summary statistics and Chisquare test.
\end{abstract}

Keywords: Public Sector Banks, Private Sector Banks, New Public Sector Banks, Summary Statistics and Chi-square Test.

\section{INTRODUCTION}

In the recent years in India house prices are rapidly rising due to lack of well-developed market and an unremitting shortage of housing. Housing is an important sector for any economy as it has interlinkages with nearly 269 other industries. The development of housing sector can have direct force on employment generation, Gross Domestic Product (GDP) growth and consumption pattern in the nation. In the country Housing is develop to help, there is need to have a well-developed housing finance market. In India, housing finance market is still in its budding stage compared to other countries. The outstanding amount of housing finance from all starting place in accounts for less than 8 per cent of GDP when compared with 12 per cent in China, 29 per cent in Malaysia, 46 per cent in Spain and 80 per cent in the US. Housing Finance Companies are losing their traditional ascendancy to Commercial Banks. With rising demand for mortgages and increasing incomes, banks began to hub on swiftly building their mortgage portfolios and now have the larger market share, providing funding to about $75 \%$ of the market. The several factors are responsible for the growth of this sector. These include for eternity rising demand, affordability of real estate, rising level of disposable income, increasing competition, lowering interest and Government policies. The Housing Finance Companies and Indian Commercial Banks control $90 \%$ of the market.

Housing finance is a very important component of retail lending books of banks. As a major incentive for banks in affordable housing finance, the Reserve Bank India (RBI) allowed banks to issue infrastructure bonds, with substantial regulatory advantages. The demand for housing is everincreasing with the growing population and urbanization and access to housing finance needs to keep pace with it; therefore, the regulators, lenders and other market participants need to be incentivized to continue to progressively cater to the growing housing finance needs. Enhancing access to housing finance plays a quintessential role in meeting the growing demand for housing. A large population of the country lives in substandard living conditions and there is dire need for improved sanitation, basic infrastructure and affordable housing. Deep, resilient and affordable housing finance markets are necessary for the middle and lower income households to manage formal housing. The policy initiatives of the government of India to propel the access to housing finance and to make it sustainable and viable for the financiers are much needed. Increasing access to capital markets, long 
term funds, facilitating regulations, etc. have been key efforts from the government and the regulators. However, there is a lot of ground to cover. National Housing Bank has also been proactively registering more and more housing finance companies to cater to areas ignored by conventional lenders thus far. The recent surge in housing finance companies from 33 to 89 companies, and the urge to spread them geographically also gives a perspective of the regulator to offer inclusive growth.

Housing finance is one of the leading employment generating industries of the Indian economy. A jump in talent demand is seen in the year 2017. Talent acquisition teams or individuals are required to show their resourcefulness, speedy implementation, leadership skills, communication and convincing skills to hire talent in this industry.

Owning one's own home is one of the defining elements of the Indian dream. But, few year ago, this part of the dream seemed to be desertion away. After 50 years of continuous progress, homeownership has become reachable, and the Nation's home-ownership rate has risen. Making homeownership more within reach has become the goal of banking and non Banking Financial Institutions. A requirement for consumers to make good decisions is to have all the relevant information about the decision at hand. Decisions are taken on the basis of the perception individual has. Addressing this issue, the purpose of this study is to investigate what perception consumers have when they search for information, predominantly when looking for a home loan.

A loan is a type of debt. Like all debt instrument, it necessitates the redistribution of financial assets over time. This service is usually provided at a cost, referred to as interest on the debt, the temporary provision of money, usually at interest. A loan can be both protected and unsecured. A "home loan" is a credit to a consumer for the purchase or alteration of the private immovable property he owns or aims to obtain secured either by a mortgage on immovable property or by a collateral commonly used in a Member State for that purpose. (www.hypo.org/Content/Default.asp). Examples of different types of home loans are: basic or "no frills" loans, standard variable rate loans, fixed-rate loans, packaged home loans, no deposit loans, non-conforming loans etc.

The basic requirements of mankind are food, clothing and safe place of safety. After food and clothing, housing is the primary necessitate of the human beings. House brings a profound social revolutionize in the existence of a person and provides an identity to him in the society. A house provides social and economic security. It is a known fact that year after year more people are added to the category of homeless as the population is on the increasing trend. The growing population makes it impossible to construct houses and gratify this need for all the people in much loved portions. It is to be tacit that everyone wants to have house constructed either through own money or borrowed funds.

Housing finance is a term which covers financing at all stages in thedevelopment of housing-purchase of land, construction and installation of on-siteinfrastructure. The project of house edifice is quite distinctive from others. Theprice factor involved in house construction needs to be taken into account. The priceshould be paid mostly in cash at the time of its use. In other words, finance for aproject of house construction is required at three stages viz.,, purchase of land, erection of house, and repayment of loan amount if borrowed funds are involved.Housing finance is a factor ofproduction moderately distinct from labour, materials and menace taking.

\section{IMPORTANCE OF Housing Finance}

From the foregoing definition it is evident that housing sector is indissolubly linked with the financial sector. The fact is that housing is a very expensive commodity which needs cavernous capital outlay testifies to the very important role of finance in housing sector. In fact, housing leans heavily on finance which makes housing function of finance to ample extent.

Housing is a function of finance. As seen earlier, land in this country is more precious than most other commodities and, therefore, purchase and development of house-sites involve a substantial amount of finance. Similarly, actual building of a house is quite expensive because it involves purchase of costly building materials and labour. Further, the fact that kutcha, decaying and impoverished dwellings constitute as much as 77 per cent of talking the problems of reconstruction or repair and maintenance. Since these kutcha houses are made of local materials, they are to be destroyed and reconstructed in two-to-three year's time. This also involves huge capital investment.

On the top that, taxes, was paying off charges, charges to cover risk involved in long-term investment, and so on. call for an additional substantial amount. Thus to find finance is perhaps the most hardhitting assignment for all those who are concerned with housing sector. 


\section{RISK INVOLVED IN HOUSING FINANCE}

Over and above problems, housing finance hackles with several risks. These risks originate from the peculiarity of housing commodity. Because of its uniqueness the housing market is unsteady and unorganized. Its prices or rents are liable to violent fluctuations. Houses are much less up for grabs than most other forms of investment. Housing selling is a time-taking business. It is difficult to set out of old house. The fissure between the prices or rents of old and new house property alerts rapidly. As the report of the United nations says, "when the breach is wide there is risk of capital loss in building or buying new residence; when gap is narrow the older houses are risky purchases."

There is always the risk that a particular house may fall in value owing to various reasons. With the passage of time the architectural style may become notorious. A cut in the public transport services or the growth of a slum may have the same effect.

House is a very meager and unsatisfactory security because of its inbuilt peculiarities. In order that, the loan may be safe and sound and secure, creditors must place accent on both the nature of the 'assets' securing the loan and the credit worthiness or the repaying capability of the borrower. Generally, the longer the term of the loan, the greater the emphasis ought to be placed on the selection of the security behind the loan. Housing needs long term finance and hence there should be greater emphasis on the security. Also, majority of the borrowers for the housing purpose have little credit worthiness. For him only tangible security is the house against which, loan may be obtained.

\section{REVIEW OF LITERATURE}

Munjee Et Al. (1990) Described That Progress Of India Towards Housing Development Largely Depends Upon Institutional Process Of Housing That Began In 1970s In India. Housing And Urban Development Corporation Was Given The Responsibility Of Financing Various House Building Agencies. Primary Co- Operative Housing Societies Were Encouraged To Be Formed Which Were Financed Through LIC That Had Specific Resources For This Specific Purpose. With The Establishment Of Housing Finance Development Corporation In The Year 1977, Housing Finance Was Regarded As Financial Intermediation Process.

Denton And Chan (1991) Determined The Underlying Factors Affecting The Selection Criteria For Banks By Multiple Bank Users. Survey Was Conducted Using Questionnaire Administered To 120 Respondents Using Quota Sampling. Analysis Was Done Using Factor Analysis And T-Test. Eight Factors Were Extracted From Thirty Statements Using Principle Components Analysis With A Varimax Rotation. These Factors Related To (A) Risk Reduction Strategies, (B) Convenience, (C) Special Circumstances Or Unusual Happenings, (D) Quality Of Service Of Banks And Relative Advantage (E) Decisions Regarding Advantages Of Banks, (F) Number Of Banks In Use And The Amount Available (G) Prestige Of Using Multiple Banks (H) Availability And Use Of Credit Cards. T-Test Revealed That Males Were Influenced By The Need For Risk Reduction Through Diversification, The Opinions Of Business Associates, The Number Of Branches Available, The Amount Of Available Credit, Getting A Credit Card And The Level Of Professionalism Of The Bank. Younger Adults Were Influenced More By The Need And Usage Preferences For Credit Cards, Whereas, Older Group Was Influenced By Maximising Rate Of Returns, Taking Advantage Of Each Banks ${ }^{\text {ee }}$ Relative Strength, Opinion Of Friends, Unmarried Are More Influenced By Convenience Rather Than Taking Advantage Of The Banks. Higher Income Group Was Influenced More By The Need To Have Access To More Bank Branches And They Use More Services Of The Banks. Highly Educated People Were Influenced By The Need For Diversification To Reduce Risk. The Relative Professionalism Of Banks And The Common Perception Of Having Multiple Bank Accounts And They Used More Of Banking Services.

Patel (1996) Had Explained That Housing Finance Has Been An Integral Part Of Bankes Priority Sector Lending. Every Nationalised Banks Is Expected To Allocate A Specific Percentage Of Deposits For Housing Finance Every Year, I.E., To Provide Housing Finance To Weaker Sections Of Society From 1975 Under The Twenty Point Programme. For Providing Planned And Systematic Housing Finance To Customers Many Banks Have Established Their Own Housing Finance Subsidiaries.

Talaga And Buch (1998) Studied How Consumers Of Mortgage Instruments Make Adjustment Among Different Instruments. The Study Focussed On Five Variables: Number Of Points, Reputation 
Of Lender, Type Of Mortgage, Additional Fees And Term Of Mortgage, Whereas The Interest Rate Was Controlled Variable. Using Conjoint Analysis It Was Found That The Most Preferred Mortgage Was That Was Fixed, No Points, No Additional Cost And Known Lender. It Was Followed By Fixed, 15 Years, No Additional Cost, No Points And Known Lender. The Important Variables That Were Recognized In The Study Were Additional Costs And Number Of Points.

Devlin (2002) Studied The Choice Criteria Followed By Consumers In Choosing The Financial Institution And The Importance Of Demographic Factors And Customers Maturity In Affecting Choice Decision. Using Judgemental Survey, Questionnaire Was Administered To Respondents That Generated 4200 Responses From Individuals Who Had Chosen A Home Loan Institution. Techniques Like T-Test And ANOVA Were Used To Find Out The Results. From All The Criteria That Were Selected In The Study From Previous Literature, It Was Found That Professional Advice Is The Most Cited Choice Criteria. It Was Also Found That Females Choose A Mortgage Primarily From An Institution Where They Already Have An Account. Individuals From Lower Social Class And Low Household Income, Asian Ethnicity, Location Whereas Those From Higher Social Class And High Household Income Choose On The Basis Of Previous Mortgage. Individuals From Non-White Ethnicity Choose Mortgage Institution On The Basis Of Image And Reputation Of The Provider. They Also Consider Service Quality While Choosing. Individuals With Low Education Choose On The Basis Of Cash Back Being A Part Of The Product Features, Attractive Interest Rate And Availability Of Discounts. It Was Seen That Individuals With High Financial Maturity Choose On The Basis Of Previous Mortgage, Interest Rates And Those With Low Financial Maturity Choose On The Basis Of Professional Advice.

Lee And Marlowe (2003) Studied The Decision Making Criteria Of Consumers In Choosing A Financial Institution. Two Independent But Related Studies Were Conducted. In First Study, Consumer Decision Making Criteria Were Analyzed While In Second Study Consumer Decision Making Heuristics Were Identified. In First Study, Data Was Taken From The Survey Of Consumer Finances And An Analysis Was Done Using Descriptive Statistics, Bivariate Statistics And Multi Nominal Logit Analysis. The Variables Included Were Experience With Checking Accounts, Socioeconomic Status And Demographic Characteristics. Findings Had Shown That Convenience Was Considered An Important Criterion By Most Of The Respondents. It Was Also Seen That Consumers"e Decision Making Criteria May Vary Across The Experiences With Checking Accounts, Socioeconomic And Demographic Characteristics. In The Second Study Data Was Collected Using A Focus Group Methodology. Findings Show That Convenience Was Considered Important By Most Of The Respondents Followed By Low Fee And Personal Relationships. Consumers Considered Location, Hours Of Operation, Online Banking As Convenience Features.

Manoj (2010) examined the operational efficiency and competitiveness of HFCs in India. This study analyzed the problems and challenges faced by HFCs particularly in comparison with commercial banks and operational efficiencies of major HFCs. It concluded that HFCs are facing more number of challenges in comparison with commercial banks and HFCs concentrate more on operational efficiency in order to survive. With the vital development of ROE (Return on Investment) the HFCs need constant control to enhance the operational efficiency of HFCs and large HFCs having an advantage over the smaller ones in sourcing cheap funds and better efficiency.

Minnesota Housing (2011) in a study examined the economic impact of Minnesota housing investment on the job and employment of the country. The study analyzed the three effects (direct, indirect and induced) of housing on the development of the country. The data was collected for five types of housing activities- multifamily new construction, multifamily rehabilitation, multifamily project with mix of new construction and rehabilitation, single family new construction and single family rehabilitation and home improvement. Single family rehabilitation and home improvement programs generally support more jobs per million dollars of spending than the other programs.

\section{Methodology}

Today, housing finance is top position in the financial sector. Housing finance companies play a vital role in the nationalized economy. However, the housing finance banks are fast flourishing; they face problems due to various reasons. Normally the local bodies make unreasonable delay to consent the sites and plots. So house builders find it difficult to get sanction of their sites, without which they can't borrow loans. 
There are some laws which are harmful to development of housing sectors like Urban Land Ceiling Act and Rent Control Act. These Acts should be amended so as to make them appropriate for the changing needs of the society. The growth of population results in the shortage of housing incessantly. The Government's initiative for the development of housing is not up to the mark and is not in sustaining of the successful implementation of this scheme. The cost of construction goes on increasing as the cost of land is space rocketing and also the labour and material costs increase constantly. The lending banks too have enhanced their rates of interest.

The majority of deprived people dwell in rural areas. They don't have regular monthly revenue as employment opportunities are less in rural areas. With no or less savings rural community people are incapable to think of their own houses. Many banks publicize low rates of interest for housing. But in reality interest rates are high as they add them with the principal every quarter in a year. They also include processing fee and other secreted charges. These are quite contrary to their advertisements.

Moreover, the housing finance banks advance loans mainly to the salaried class in India. The rural community people, unorganized non-regular income groups find it difficult to avail the housing loan competence. Hence an attempt is made to study the availing the housing finance in Tamilnadu - A study with special reference to Thanjavur district. In such a situation the following factors are important for the analysis.

- At what levels the various housing finance institutions renders services to utilize of housing finance?

- What the advantages resultant was by utilizes of housing finance and the housing finance banks?

- What is the role of housing finance banks in achieving their objectives?

- What are the steps taken by housing finance institutions to meet the competitions in the market?

\subsection{Objectives Of The Study}

- To appraise the housing situation in the country in general.

- To review the housing finance system in India

- To study the customer services rendered by the various housing finance institutions

- To scrutiny the financial performance of selected housing finances institutions.

- To analyze the problems and experience of the customers availing housing loans in Thanjavur District

- To find out the problems faced by the housing finance institutions

- To imply better ways for marketing the housing fiancé service and to accomplish the level of customer satisfaction in their services.

\subsection{Hypothesis}

- There is no relationship between hosing loan borrowers and income level.

- There is an association between duration taken by the ban for sanctioning the loan and duration of sanction the loan.

\subsection{Sample Design and Data Collection}

The sample for this study was selected from different bank's customer in Tambaram City. Given the nature of this study, a non-probability (convenience) sampling was chosen. Self-administered surveys were distributed in 2019. Respondents were assured of the confidentiality of their responses and their names and account no. were not solicited. A total of 240-questionnaire distributed, out of which 180 were collected to the house loan borrowers of three banks named Indian Overseas Bank, Indian Bank, State Bank of India distributed in Tambaram city.

Data was collected on both primary data and secondary data. Primary data were collected through survey method and secondary data were collected through published records and banking journals, various articles etc.

In this research the researcher has used various statistical tools like simple tables diagrams, ranking technique and chi square analysis and simple ranking technique. 


\subsection{Limitations of the Study}

- Some respondents were wavering to give true responses.

- The data was collected within 2 month time period.

- The inferences apply only to the respondents of Tambaram City and are not pertinent to any other place and cannot be indiscriminate.

\section{RESUlT AND DISCUSSION}

In the present scenario house loan borrowers prefer the public sector banks and private sector banks differ from one person to other person, so to understand preference of different customer the researcher have used various dimension such as usage of farmers, business people for construction, renovation, availing tax exemption the customers or house loan borrowers borrowing the loan to the various banks.

Table1. Analysis of Demographic Variables

\begin{tabular}{|c|c|c|c|}
\hline Variable & Category & Frequency & Percentage \\
\hline \multirow{2}{*}{ Gender } & Male & 130 & 72.22 \\
\hline & Female & 50 & 27.78 \\
\hline \multirow{5}{*}{ Age (in years) } & Below 30 & 65 & 36.11 \\
\hline & $30-40$ & 35 & 19.44 \\
\hline & $40-50$ & 40 & 22.22 \\
\hline & $50-60$ & 25 & 13.89 \\
\hline & Above 60 & 15 & 8.34 \\
\hline \multirow{5}{*}{ Educational Qualification } & Upto SSLC & 35 & 19.44 \\
\hline & Hr.Sec & 30 & 16.67 \\
\hline & Degree & 75 & 41.67 \\
\hline & Professional & 25 & 13.89 \\
\hline & Diploma & 15 & 8.33 \\
\hline \multirow{4}{*}{ Occupation } & Business & 45 & 25.00 \\
\hline & Employee & 60 & 33.34 \\
\hline & Farming & 35 & 19.44 \\
\hline & Professional & 40 & 22.22 \\
\hline \multirow{5}{*}{ Monthly Income } & Below Rs.20,000 & 80 & 44.44 \\
\hline & Rs.20,000 - Rs.30,000 & 28 & 15.55 \\
\hline & Rs. 30,000 - Rs. 40,000 & 30 & 16.67 \\
\hline & Rs. 40,000 - Rs.50,000 & 30 & 16.67 \\
\hline & Above Rs. 50,000 & 12 & 6.67 \\
\hline
\end{tabular}

\section{Source: Primary Data}

Above Table 1- shows that most of the respondents are men (72.22\%), they are income earned people in the familyin research area as compared to women in the Tambaram city. On a Percentage basis, below 30 years of age groups fall on $36.11 \% .41 .67 \%$ of respondents' qualification is only Degree level in the study area. Out of 180 respondents, $33.34 \%$ of them are employee and remaining fall under other category. Out of 180 house loan borrowers $44.44 \%$ of them earn the monthly income of below Rs.20, 000 (i.e. employee and farming).

Table2. Types of Housing Loans Covered

\begin{tabular}{|l|l|l|}
\hline Housing loan types & No of customers & Percentage \\
\hline Purchase of house & 85 & 47.22 \\
\hline Construction of house & 40 & 22.22 \\
\hline Renovation and up gradation & 25 & 13.88 \\
\hline Purchase of land & 20 & 11.11 \\
\hline Home conversion loan & 10 & 5.57 \\
\hline Total & 180 & 100 \\
\hline
\end{tabular}

\section{Source: Primary Data}

Table 2 clearly exhibits that the customers borrowing the loan for the coverage of various purposes. Out of 180 respondents $85(47.22 \%$ ) respondents say that only for the purchase of loan is purchase of house, this type of loan is mostly arranged by the builders; 22.22 per cent of the customers say that construction of the house. Few customers can getting loan for home conversion loan. 
Table3. Analysis of Complexity Faced by House Loan Borrowers for Getting House loan

\begin{tabular}{|l|l|l|l|}
\hline \multicolumn{1}{|c|}{ Variable } & Category & Frequency & Percentage \\
\hline \multirow{4}{*}{ Duration for sanction of loan } & $0-1$ month & 35 & 19.44 \\
\cline { 2 - 4 } & $0-2$ month & 45 & 25.00 \\
\cline { 2 - 4 } & $0-3$ month & 80 & 44.44 \\
\cline { 2 - 4 } & More than three months & 20 & 11.12 \\
\hline \multirow{3}{*}{$\begin{array}{l}\text { Duration taken by the bank in sanctioning the } \\
\text { loan }\end{array}$} & Very little & 80 & 44.44 \\
\cline { 2 - 4 } & Justified & 35 & 19.44 \\
\cline { 2 - 4 } Handing out charge of the bank & Long enough & 40 & 22.23 \\
\cline { 2 - 4 } & Very low & 25 & 13.88 \\
\hline \multirow{4}{*}{ Paper work for the loan } & Very high & 50 & 27.78 \\
\cline { 2 - 4 } & Moderate & 85 & 47.22 \\
\cline { 2 - 4 } & Low & 45 & 25.00 \\
\hline & Highly satisfied & 42 & 23.33 \\
\cline { 2 - 4 } & Satisfied & 28 & 15.56 \\
\cline { 2 - 3 } & Moderate & 64 & 35.56 \\
\cline { 2 - 3 } & Dissatisfied & 30 & 16.67 \\
\cline { 2 - 3 } & Highly dissatisfied & 16 & 8.88 \\
\hline
\end{tabular}

\section{Source: Primary Data}

From the above table 3 clearly indicates that, the various difficulties faced by the housing loan borrowers for getting house loan. 44.44 per cent of the borrowers feel that the duration for sanction of house loan the period was taken by the bank is $0-3$ months; 11.12 per cent of the bankers are taken by the period is more than three months for sanction the loan especially for SBI. 44.44 per cent of the borrowers say that very little duration taken by the bank in sanctioning the loan. The borrowers opined that the processing charge of the bank was moderated (47.22\%) for the SBI, IOB, Indian Bank as compared to other banks and the satisfaction level of the paper formalities for the house loan paper work of the loan 35.56 per cent of the borrowers are moderately satisfied followed by highly satisfied but 16.67 per cent of the customers say that dissatisfied for the paper work for the bank loan more paper work in the banks.

\subsection{Verification of Hypothesis}

In order to prove this fact, the researcher has framed the following null hypothesis that $\mathbf{H}_{\mathbf{0 1}}$ "There is no association between preference made by house loan borrowers for choosing the specific bank and selection of banks in the study area.'To validate this promulgation, the researcher has used the ChiSquare Technique.

Table4. Preference made by the house loan borrowers for choosing the specific bank in Tambaram sub urban and selection of bank

\begin{tabular}{|l|l|l|l|l|}
\hline Preference & \multicolumn{1}{|c|}{$\begin{array}{c}\text { Indian Overseas } \\
\text { BanK }\end{array}$} & \multicolumn{1}{|c|}{ Indian Bank } & \multicolumn{1}{|c|}{ Total } \\
\hline More branches & $55(30.56 \%)$ & $40(22.22 \%)$ & $85(47.22 \%)$ & $180(100 \%)$ \\
\hline $\begin{array}{l}\text { Easy and low processing } \\
\text { fee }\end{array}$ & $80(44.44 \%)$ & $60(33.32 \%)$ & $40(22.22 \%)$ & $180(100 \%)$ \\
\hline Low interest rate & $45(25.00 \%)$ & $85(47.22 \%)$ & $50(27.78 \%)$ & $180(100 \%)$ \\
\hline Fast sanction of loan & $50(27.78 \%)$ & $90(50.00 \%)$ & $40(22.22 \%)$ & $180(100 \%)$ \\
\hline Total & $230(31.94 \%)$ & $275(38.19 \%)$ & $215(29.86 \%)$ & 720 \\
\hline
\end{tabular}

\section{Source: Computed data}

Calculated chi- square value is 29.36 - significant (at 6 degrees of freedom table value is 12.592 at $5 \%$ level of significance)

The computed Chi-Square value is 29.36 is more than the table value 12.592. So the null hypothesis is rejected.

Hence, it was concluded that, $\mathrm{H}_{01}$ "There is an association between preference made by house loan 


\subsection{Findings of the Study}

- It is lucid that Most of the respondents are men (72.22\%) for the study.

- It is vivid that majority of the borrowers are income earned people in the family in research area as compared to women in the Tambaram sub urban.

- It is preponderance that majority (36.11 per cent ) of the borrowers are come under the age group of below 30 years.

- $41.67 \%$ of respondents' qualification is only Degree level in the study area.

- Out of 180 respondents, $33.34 \%$ of them are employee and remaining fall under other category.

- $44.44 \%$ of them earn the monthly income of below Rs.20, 000 (i.e. employee and farming).

- The customers are borrowing the loan for the coverage of various purposes. Majority $85(47.22 \%)$ respondents say that only for the borrowing the loan is purchase of house, this type of loan is mostly arranged by the builders.

- Majority 44.44 per cent of the borrowers feel that the duration for sanction of house loan the period was taken by the bank is 0-3 months.

- The borrowers opined that the processing charge of the bank was moderated (47.22\%) for the SBI, IOB, Indian Bank as compared to other banks.

\section{Conclusion}

To conclude this study, it can be generalized that there are key difference in the actual purchase of the consumers of the housing loans of Public sector banks, public sector banksand New generation public sector banks. As regards the important product traits are concerned, litheness, processing fees, processing period and interest rates plays a major role in all the three types of banks. Consumers of housing loans of the New generation public sector banks are making smaller number of visits to the bank to avail the loan than others.

Housing sector is one of the sectors where black money is invested. But unfortunately it has also become a sector where white money is converted to black money by even honest people as they have to pay in black to buy a house for which they may have to take a loan (not housing, but personal loan).

\section{Suggestions for this study}

- Banks should be provide different housing loan schemes with attractive features like rate of interest, margin etc. for attractive more and more people in rural area.

- Housing schemes and procedure of passing loan should be simple to make the people know.

- Rate of interest should be spirited with other pecuniary institutions.

- Proper credit appraisal of the customer should be made.

- Counter facility should be provided in all banks to help the borrowers.

- To attract more customers, banks should make process of loan repayment easy.

\section{REFERENCES}

[1] Denton, L.T., and Chan. A.K.K. (1991), Bank Selection Criteria Of Multiple Bank Users In Hong Kong. International Journal Of Bank Marketing, Vol.9, No.5, pp.23-24.

[2] Devlin, J.F. (2002), An Analysis Of Choice Criteria In The Home Loans Market. International Journal Of Bank Marketing, Vol. 20(5), pp. 212-226.

[3] Frangos, C., Fragkos, K., Sotiropoulos, L. Manolopoulous, G. And Valvi, A. (2012).Factors Affecting Customeres Decision For Taking Out Bank Loans: A Case Study Of Greek Customers. Journal Of Marketing Research And Case Studies. Www.Ibimapublishing.Com/Journals/JMRCS/Jmrcs.Html, Article Id: 927167, pp. 1-16

[4] Ghose, Brat, Shiva. (1987). Housing Shortage And Its Impact On Environment: An Overview In Indian Context. Civic Affairs 
[5] King, P. (2001). Understanding Housing Finance. Routledge, London and New York.

[6] Kohli, V.K. (2007) Housing Finance Agencies in India. Deep \& Deep Publication Private Limited, New Delhi.

[7] Sangwan, P., Bhan, K. (2012) A Comparative Analysis On Home Loans Of Public And Private Sector Banks In India. International Journal Of Research In Commerce, Economics And Management, Vol. 2, No. 9, Pp.121-125

[8] www.Nhb.Org.In

[9] www.Rbi.Org.In

[10] www.Housingfinance.Org

Citation: Dr. G. Manimannan, et.al., (2019). Customer Preferences of Housing Finance in Chennai with Special Reference to Sub Urban of Tambaram. International Journal of Scientific and Innovative Mathematical Research (IJSIMR), 7(7), pp. 15-23. http://dx.doi.org/ 10.20431/2347 -3142.0707005

Copyright: (C) 2019 Authors, this is an open-access article distributed under the terms of the Creative Commons Attribution License, which permits unrestricted use, distribution, and reproduction in any medium, provided the original author and source are credited. 